\title{
PERCEPTIONS OF LOCAL COMMUNITIES ON WATER QUALITY IN PAGBANGANAN RIVER, BAYBAY CITY, LEYTE
}

\author{
Eunice Kenee A. Labonite, Moises Neil V. Seriño ${ }^{2}$ \\ and Beatriz S. Belonias ${ }^{3}$ \\ 'Instructor; Bobol Island State University' - Bilar Campus, Bobol, Pbilippines \\ ${ }^{2}$ Instructor and ${ }^{3}$ Professor \\ Visayas State University Visca, Baybay' City 6521-A \\ Leyte, Pbilippines
}

\begin{abstract}
Pagbanganan River is a river system that traverses several barangays in the city of Baybay. The river is important to the communities because of its various ecological uses. At this time, however, it is facing major threats which affect its water quality. This study was conducted to find out how the people living near the river utilize the water resources and to determine some economically important biological resources derived from the river. River-related problems, traditional practices, superstitious beliefs and their perception on water quality were assessed. Personal interviews were conducted to gather data on household characteristics, water usage and assessment of water quality. The communities residing near the river belonged to low-income families. Many of them depend on the river for food and other services. Fish, shrimps, crabs and snails are among the many biological resources derived from the river. Most residents considered the river as important to them. Respondents generally believed that the river's water quality has been slowly deteriorating. Overall findings suggest the need to raise public awareness on water quality issues to increase people's understanding and encourage them to adopt practices that can sustain the river's health.
\end{abstract}

Key words: River system, water quality, water use 


\section{INTRODUCTION}

Rivers are considered as among the most important resources in the Philippines. These freshwater bodies are very important components of the biosphere because of their role in the water cycle and in carrying nutrients to the environment. Rivers provide excellent habitat and food to various kinds of organisms. Despite the vital roles of rivers, they are currently threatened by a host of water quality problems (Vié et al., 2009). With the increasing concerns over water contamination by agricultural run-off, organic material, fertilizer and other potential contaminants, attention to water quality is an absolute requirement for the health of lotic freshwater ecosystems.

Pagbanganan River is one of the 12 major river systems in the island of Leyte. It plays an important role in the community since the people derive various resources and services from it. The river system is primarily used for irrigation on some agricultural lands in the lowland areas and it also supplies water for domestic use (Alvarado, 2005). Initiatives to sustain a river's health should consider the perception of the local inhabitants and thus the need to gather socioecological perceptions. Socio-ecological perception reflects the interactions of bio-geophysical dynamics with associated social actors and institutions in human-dominated ecosystems (Redman et al., 2004).

This study investigates the socio-ecological perceptions of local communities residing near Pagbanganan river. It specifically aimed to determine the socio-economic profile and document cultural practices of the residents; assess how the people utilize the water resource; identify some economically important biological resources derived from the river; evaluate some river-related problems, traditional practices and superstitious beliefs; and determine how the people in the area use local knowledge in determining water quality. 


\section{MATERIALS AND METHODS}

\section{Analytical Framework}

This study adopted the framework developed by Bennett et al. (2009) where river system provides important ecological services to the society (Figure 1). In return, the society affects the river systems by extracting biological and non-biological resources to satisfy its needs. This framework was used in evaluating the social influence on the ecological health of the river system. In this current study, we focused on the social factors by evaluating their practices related to the river system and assess their perceptions on water quality.

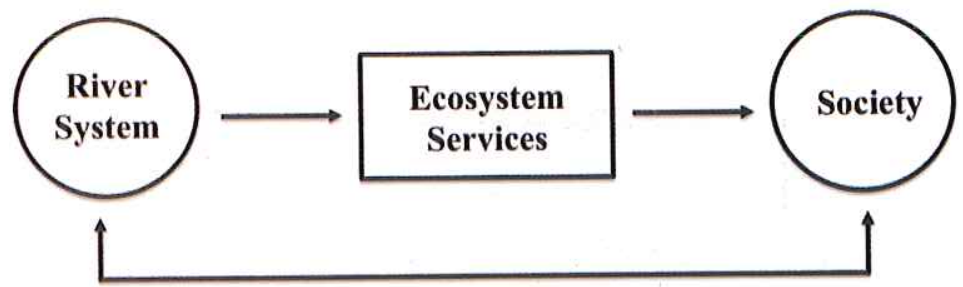

Figure 1. Theoretical framework capturing the relationship between society and the environment

\section{Locale and Respondents}

The study was conducted in two barangays of Baybay City, namely, Brgy. Igang and Brgy. Kantagnos. Considered as the key stakeholders of Pagbanganan River, these communities were the sites of a planktonic assessment conducted by Labonite and Belonias (2013). Their findings detected the presence of some phytoplankton genera that are good bioindicators of water quality. 
This socio-ecological assessment on the perception of local communities will hopefully complement the biological assessment conducted by Labonite and Belonias (2013).

Site 1 (upstream) was in Brgy. Kantagnos and sites 2 (midstream) and 3 (downstream) were located in Brgy. Igang (Figure 2). Households residing near the river were considered as part of the population of the survey considering that they are the main stakeholders in the area.

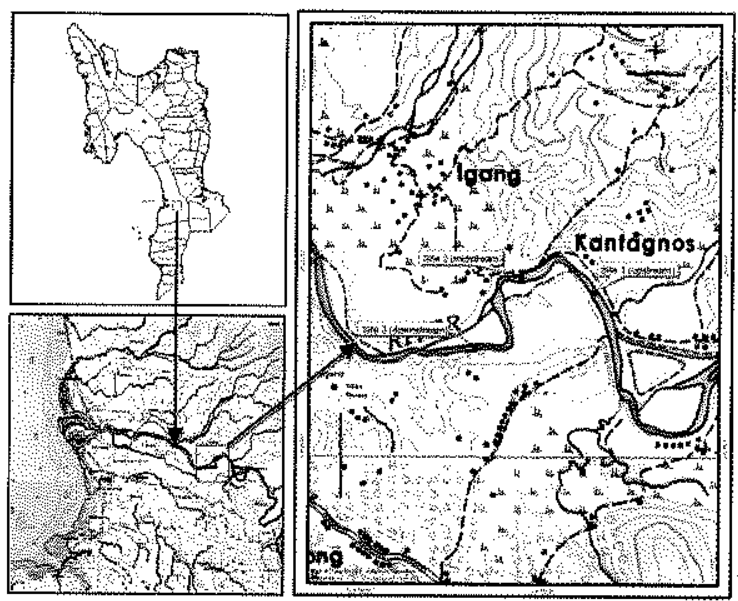

Figure 2. Map of Pagbanganan River, Baybay City showing the three sampling stations

To determine the adequate sample size, the Slovin's formula was used. Slovin's formula is commonly used in determining the sample size when the total population is known (Ellen, 2011). It is also a simplified formula in sampling since the researcher can allocate a certain margin of error to take into account the allowable error of the sample taken randomly from the whole population. In computing the sample size for this study, $10 \%$ margin of error was used. The total households residing near the river from Brgy. Igang was 288 while from Brgy. Kantagnos was 53 households. This comprises the total population of 341 households. 
Given this information, the required sample size was computed at 77 households. Table 1 presents the proportionate allocation of the respective sample size in every barangay and to every sitio.

Table 1. Proportionate allocation of households to sitio under Brgy. Igang and Brgy. Kantagnos

\begin{tabular}{cccccc}
\hline Brgy. Igang & Population & $\begin{array}{c}\text { Sample } \\
\text { size }\end{array}$ & Brgy. Kantagnos & Population & $\begin{array}{c}\text { Sample } \\
\text { size }\end{array}$ \\
\hline Bombil & 77 & 17 & Avocado & 22 & 5 \\
Gumamela & 49 & 12 & Nangka & 13 & 3 \\
Rosas & 86 & 19 & Santol & 18 & 4 \\
Waling-waling & 76 & 17 & & & \\
\hline Total & 288 & 65 & Total & 53 & 12 \\
\hline
\end{tabular}

In determining the number and name of households that were interviewed, the following procedure was adopted:

i. The list of household heads was obtained from the City Administration's Office of Baybay, Leyte after asking permission from the barangay captain;

ii. To ensure that every household was given an equal chance to be selected as sample of the study, random sampling was done using the randomized procedure in MS Excel; and

iii. Alternate sample households were drawn to serve as replacement of selected households in case of absence of the household head at the time of the interview or refusal to participate in the survey.

\section{Formulation of Questionnaire and Pre-Testing}

A questionnaire was formulated to capture the necessary information on household characteristics, water usage and assessment of water quality in Pagbanganan River. After formulating the questionnaire, it was pre-tested to evaluate its appropriateness and make further adjustments for items needing revision. 


\section{RESULTS AND DISCUSSION}

\section{Demographic Characteristics}

The respondents age ranged from 14 to 85 years old with an average age of 47.71 years and are composed of $44 \%$ male and $56 \%$ female (Table 2). More than $80 \%$ were married and in terms of educational attainment, $54 \%$ of the respondents were elementary graduate, $36 \%$ reached high school and only $10 \%$ graduated from college. For household structure, $61 \%$ had a nuclear family and for religion more than $90 \%$ were Roman Catholic. Members of the households ranges from one member to 13 family members with an average family size of six. There were one to ten children per family with an average of four and only an average of two children per household were attending school.

For those children attending school, 93\% were in public schools, which could be due to the proximity to the public schools and the low cost of sending kids to public schools compared to private schools. For those children who were not able to attend school, the reasons were due to marriage, below school age, old age, no interest in school at all and some mentioned financial problem.

The respondents have been residing in Brgy. Igang and Brgy. Kantagnos for three to 85 years already with an average of 40 years. About $70 \%$ were native to the barangays and the rest were migrants from nearby barangays within Baybay, from Cebu and from other neighboring provinces. The main reason why respondents moved in was because of marriage. 
Table 2. Demographic characteristics of residents along Pagbanganan River

\begin{tabular}{|c|c|c|c|c|}
\hline Socio-Demographic Variables & $\mathrm{N}$ & Mean & Min & Max \\
\hline Age of respondents & 77 & 47.71 & 14 & 85 \\
\hline Male $(1=$ male, $0=$ female $)$ & 77 & 0.44 & 0 & 1 \\
\hline Married ( $1=$ married, $0=$ other status $)$ & 77 & 0.82 & 0 & 1 \\
\hline $\begin{array}{l}\text { Elementary Level }(1=\text { elementary level, } 0=\text { other } \\
\text { level) }\end{array}$ & 76 & 0.54 & 0 & 1 \\
\hline $\begin{array}{l}\text { High School Level ( } 1 \text { wigh school level, }=\text { other } \\
\text { level) }\end{array}$ & 76 & 0.36 & 0 & 1 \\
\hline College Level $(1=$ college level, $0=$ other level $)$ & 76 & 0.10 & 0 & 1 \\
\hline $\begin{array}{l}\text { Nuclear Family ( } 1=\text { nuclear family, } 0=\text { other family } \\
\text { type) }\end{array}$ & 76 & 0.61 & 0 & 1 \\
\hline $\begin{array}{l}\text { Roman Catholic }(1=\text { Roman Catholic, } 0=\text { other } \\
\text { religion) }\end{array}$ & 77 & 0.92 & 0 & 1 \\
\hline Household size & 77 & 5.66 & 1 & 13 \\
\hline No. of children & 74 & 3.77 & 1 & 10 \\
\hline No. of children attending school & 44 & 2.05 & 1 & 7 \\
\hline $\begin{array}{l}\text { Public School ( } 1=\text { public schools, } 0=\text { other type of } \\
\text { school) }\end{array}$ & 42 & 0.93 & 0 & 1 \\
\hline No. of children not attending school & 29 & 2.72 & 1 & 6 \\
\hline Yrs. of living in current residence & 76 & 40.01 & 3 & 85 \\
\hline $\begin{array}{l}\text { Native to barangay ( } 1=\text { native to the barangay, } 0= \\
\text { coming from other places) }\end{array}$ & 77 & 0.70 & 0 & 1 \\
\hline
\end{tabular}

\section{Income and Expenditure Profile}

More than one-third of the respondents $(35.3 \%)$ have no regular work and most of the time unemployed (Table 3). For those who are working, a little more than $16 \%$ are either service worker or sales worker, $14.7 \%$ are self-employed and $7.4 \%$ are barangay officials. Other forms of occupation of the respondents include agricultural worker, laborer, other professionals. This implies that more than onethird most of the respondents residing close to the river do not have a stable source of income. 
Table 3. Occupation of the respondents

\begin{tabular}{lcc}
\hline Primary occupation & Frequency & Percentage \\
\hline No regular work & 24 & 35.3 \\
Service worker & 11 & 16.2 \\
Sales worker & 11 & 16.2 \\
Self-employed & 10 & 14.7 \\
Barangay official & 5 & 7.4 \\
Laborer & 3 & 4.4 \\
Agricultural worker & 2 & 2.9 \\
Professional & 2 & 2.9 \\
\hline Total & 68 & 100 \\
\hline
\end{tabular}

The monthly income of the respondents per month ranged from 100 pesos to 20,000 pesos (Table 4). On the average, the respondents earned $\mathrm{PhP}$ 2,714.18 per month. According to the National Statistical Coordination Board (NSCB), the monthly per capita poverty threshold in rural areas of Leyte for 2007 is PhP 1,072.50 (NSCB, 2012). This threshold was used to compare if respondents are below or above the poverty line. To compute for the per capita income, we divided the average monthly income with the average household size of 5.66. Results reveal that the computed monthly per capita income of the respondents is $\mathrm{PhP} 479.54$, which is lower than the PhP 1,072.50 threshold computed by NSCB. This strongly implies that the respondents residing near the river are relatively poor. 
Table 4. Monthly income of the households

\begin{tabular}{lcccccc}
\hline Income & $\mathrm{N}$ & Mean & Median & Stcl. Dev & Min & Max \\
\hline $\begin{array}{l}\text { Monthly } \\
\text { income }\end{array}$ & 62 & $2,714.18$ & 2,000 & $3,546.7$ & 100 & 20,000 \\
\hline
\end{tabular}

We disaggregated the household expenditure into several major consumption items. The highest monthly expenditure of the respondents went to food particularly rice and viand (Figure 3 ). This was followed by education, which included children's daily allowance, school supplies, school projects and other school fees. Notably, the lowest expenditure was on water, which is logical considering that the respondents lived near the river.

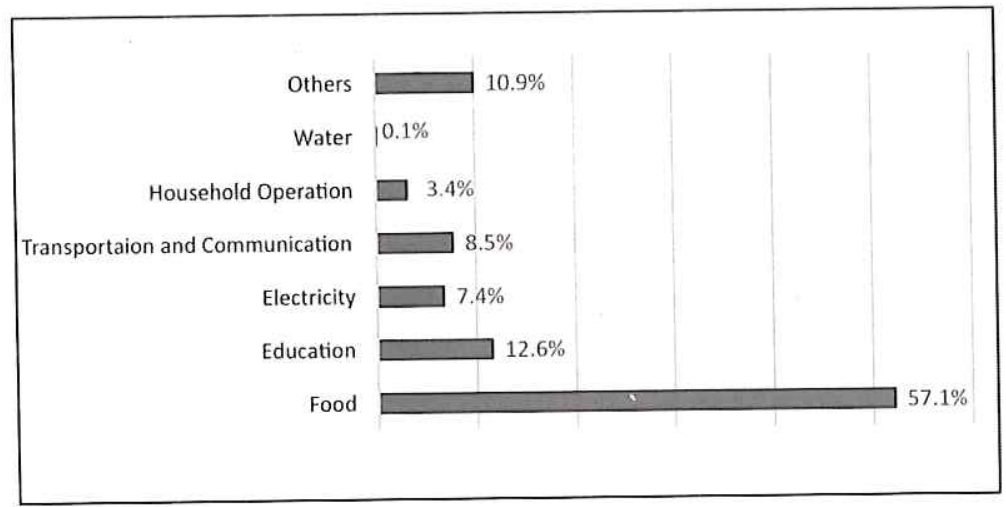

Figure 3. Monthly household expenditure

Rice consumption was the highest among household expenditure. The rice expenditure ranged from $\mathrm{PhP} 310.00$ per month to as much as $\mathrm{PhP} 3,500.00$ with an average expenditure of $\mathrm{PhP}$ 1,650.46 per month (Table 5). Since the respondents are generally 
living below the poverty line, food, especially rice, is understandably the priority. With all expenditure items aggregated, the total monthly expenditure of the respondents is $\mathrm{PhP} 3,887.87$. This shows that monthly expenditure of the households is higher than their monthly income of only $\mathrm{PhP} 2,714.18$.

Two things could explain this. First, it could be that the respondents did not actually reveal their true income since income can be viewed as private and confidential. Second, even if the respondents indeed gave their real income, it could be that their expenditure was financed through credit or loans. Since the respondents are relatively poor, then it is plausible that they are earning lower than what they spend. This implies that they borrow money to support their daily needs.

Table 5. Average monthly household expenditure

\begin{tabular}{lcrrrrr}
\hline Monthly Expenditure & n & \multicolumn{1}{c}{ Mean } & Median & Std. Dev & Min & Max \\
\hline Rice & 65 & $1,650.46$ & 1,700 & 696.93 & 310 & 3,500 \\
Viand & 73 & 956.58 & 500 & $1,093.18$ & 100 & 8,000 \\
Education & 52 & 576.96 & 280 & 729.03 & 0 & 3,000 \\
Electricity & 72 & 337.04 & 150 & 453.20 & 0 & 1,600 \\
Transportation & 62 & 246.97 & 85 & 729.44 & 0 & 5,600 \\
House operation & 72 & 156.61 & 100 & 245.50 & 17 & 1,700 \\
Personal care & 72 & 154.07 & 100 & 225.83 & 6 & 1,700 \\
Communication & 46 & 139.35 & 45 & 412.37 & 0 & 2,800 \\
Water & 60 & 5.25 & 5 & 5.50 & 0 & 20 \\
Others & 46 & 343.59 & 100 & 494.72 & 0 & 2,000 \\
\hline Total Expenditure & 75 & $3,887.87$ & 3,200 & $3,287.10$ & 110 & 25,470 \\
\hline
\end{tabular}


With regards to house ownership, close to $90 \%$ of the respondents owned a house, the rest occupied somebody else's house for free. Most of the houses have either one (40\%) or two rooms $(38.6 \%)$ and were made of strong construction material such as GI sheets for roofing $(96.1 \%)$, cement for walls and flooring $(64.9 \%$ and $77.9 \%$, respectively).

About $93.5 \%$ of the houses used electricity as source of lighting and only $6.5 \%$ used kerosene lamps. For cooking, firewood was the main fuel used (88.3\%) and only $10.4 \%$ used liquefied petroleum gas or LPG. Most of the respondents have water connection from the Baybay Water District so they have their own private faucets $(40.3 \%)$ to provide them with safe drinking water. Others fetch water from a common community faucet $(31.2 \%)$ while the rest get water from a shared deep well $(26 \%)$.

\section{Sanitation Practices}

Table 6 shows how the respondents dispose their household garbage and the type of toilet they used. More than half of them $(57.1 \%)$ burn their garbage, about one-fifth (19.5\%) practice composting. Unfortunately, $16.9 \%$ of them simply dump their trash into the river. In terms of type of toilet used, $81.8 \%$ of the respondents have water-sealed toilets while, $18.2 \%$ have no toilet at all. It is also possible that those who do not have toilets are defecating in the river. This implies that some of the most likely sources of organic pollutants of the river are garbage and human waste. 
Table 6. Garbage disposal and toilet of the household

\begin{tabular}{|c|c|c|}
\hline Method of garbage disposal & Frequency & Percent \\
\hline Burning & 44 & 57.1 \\
\hline Composting & 15 & 19.5 \\
\hline Dumping in the river & 13 & 16.9 \\
\hline Burying & 3 & 3.9 \\
\hline Dumping in the community dump site & 1 & 1.3 \\
\hline \multirow[t]{2}{*}{ Dumping in the backyard } & 1 & 1.3 \\
\hline & 77 & 100.0 \\
\hline \multicolumn{3}{|l|}{ Type of toilet } \\
\hline Water-sealed & 63 & 81.8 \\
\hline None & 14 & 18.2 \\
\hline Total & 77 & 100.0 \\
\hline
\end{tabular}

\section{Utilization of the River}

Figure 4 presents how the households are utilizing the river. The six major usage of the river in order of importance are (1) source of food ( $81 \%)$; (2) for laundry (46\%); (3) for bathing (34.9\%); (4) irrigation of agricultural crops (14.3\%); (5) for wallowing carabaos $(12.7 \%)$; and (6) for washing dishes $(9.5 \%)$. Some of the food items mentioned by the respondents include fish, shrimps, crabs and some freshwater mollusks. For laundry and bathing, most of the respondents practiced bringing their dirty clothes to the river while some would just go to the river to wash clothes and take a bath when pipelines are down. Some farmers are diverting some water to irrigate their fields while others fetch water from the river to water their vegetable gardens near the river. During the conduct of the study, it was observed that kids were swimming in the downstream portion of the river while carabaos were wallowed in the upstream. 


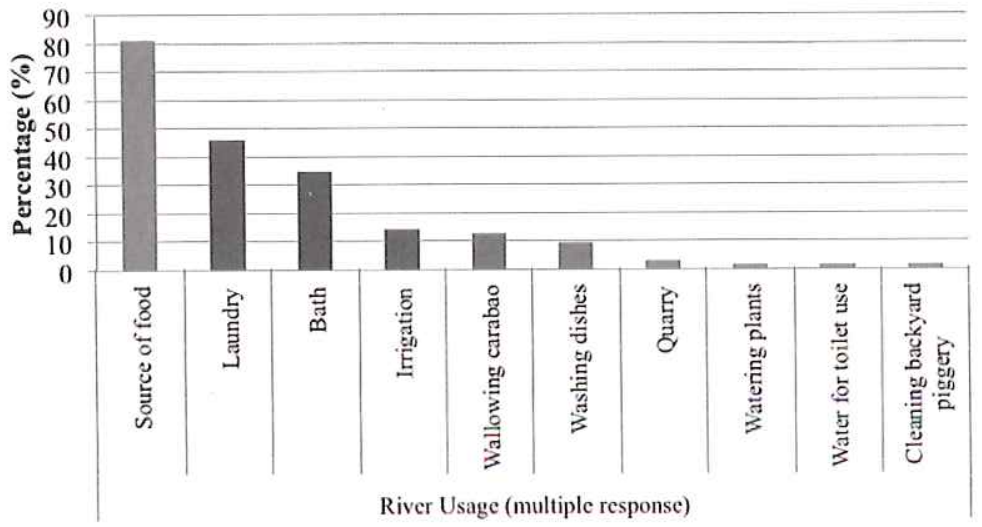

Figure 4. Use of the river by the respondents

The houses of the respondents were as close as five meters to as far as 1,100 meters from the river but at an average of about half a kilometer. Their proximity to the river explains why many have been depending on the river for various household uses. Some have been fishing, doing laundry and taking a bath in the river for almost four years already.

Table 7 shows that more than $80 \%$ of the respondents catch fish from the river, $61.7 \%$ get crabs and shrimps while $10.6 \%$ take freshwater snails. Usually, it is the father (78.7\%) who does fishing in the river although sometimes the kids and even the mother also help. About $55.26 \%$ of the respondents do fishing weekly and $36.85 \%$ do it only occasionally at times when they have no viand at home or when they want to spend their leisure time. It is then evident that the river serves as an important source of food to more than half of the residents along the river. 
For the other services derived from the river, most of the respondents do laundry every week $(35.7 \%)$ with the mother mostly doing the job $(77.8 \%)$. About half of them $(47.7 \%)$ do not use the river for regular bathing and they only do it during occasions when they have problems with the water supply in their homes. Only onefifth $(19 \%)$, however, take their regular bath in the river and they do it either daily or two to three times a weekly.

Table 7. Food resources and other services derived from the river

\begin{tabular}{|c|c|c|}
\hline & Frequency & Percent \\
\hline \multicolumn{3}{|l|}{ Type of food resource: } \\
\hline Fish & 40 & 85.1 \\
\hline Crab and shrimp & 29 & 61.7 \\
\hline Freshwater snail & 5 & 10.6 \\
\hline $\begin{array}{ll} & \text { Total } \\
\end{array}$ & 74 & \\
\hline \multicolumn{3}{|l|}{ Person getting these food resources: } \\
\hline Father & 37 & 78.7 \\
\hline Mother & 5 & 10.6 \\
\hline Siblings/kids & 8 & 17.1 \\
\hline Friends & 2 & 4.3 \\
\hline Nephew & 3 & 6.4 \\
\hline Whole family & 1 & 2.1 \\
\hline $\begin{array}{l}\text { Total } \\
\end{array}$ & 56 & \\
\hline \multicolumn{3}{|l|}{ Frequency of getting these food resources: } \\
\hline Weekly & 21 & 55.2 \\
\hline Occasionally & 14 & 36.8 \\
\hline Monthly & 3 & 7.8 \\
\hline Total & 38 & 100.0 \\
\hline $\begin{array}{l}\text { Person doing the laundry: } \\
\text { Mother }\end{array}$ & 21 & 77.8 \\
\hline Father & 2 & 7.4 \\
\hline Kids & 2 & 7.4 \\
\hline Nephew & 1 & 3.7 \\
\hline \multirow[t]{2}{*}{ Household helper } & 1 & 3.7 \\
\hline & 27 & 100.0 \\
\hline
\end{tabular}




\begin{tabular}{|c|c|c|}
\hline \multicolumn{3}{|l|}{ Frequency of doing laundry: } \\
\hline Weekly & 10 & 35.7 \\
\hline Two to three times a week & 7 & 25.0 \\
\hline Sometimes (no water in the faucet) & 7 & 25.0 \\
\hline Daily & 4 & 14.3 \\
\hline Total & 28 & 100.0 \\
\hline $\begin{array}{c}\text { Frequency of bathing: } \\
\text { Occasionally }\end{array}$ & 9 & 47.7 \\
\hline Daily & 4 & 19.0 \\
\hline Two to three times weekly & 4 & 19.0 \\
\hline Once a week & 3 & 14.3 \\
\hline Total & 21 & 100.0 \\
\hline
\end{tabular}

*multiple response

The respondents reported that there were three main economically important food resources that they derive from the river. These includes fish $(90 \%)$, invertebrates $(70.9 \%)$ and plants/vegetables (1.8\%) (Figure 5). This shows that Pagbanganan River is indeed rich in biological resources especially freshwater fish.

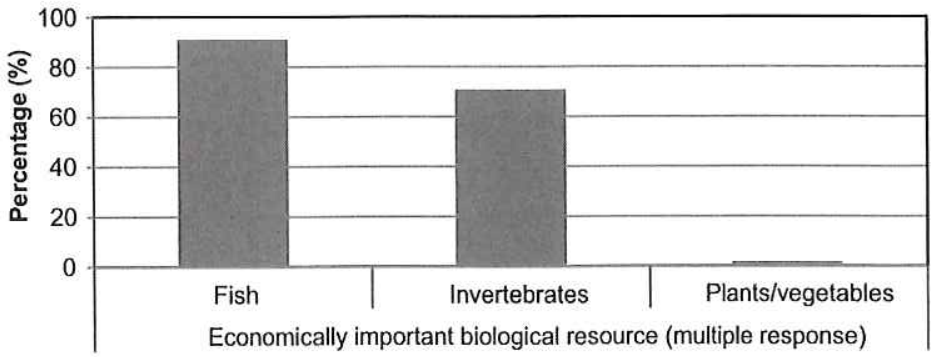

Figure 5. Economically important biological resources respondents derive from Pagbanganan River

Among the most common resources are "tilapia" fish (49.1\%), "bukgay" and "susu" snails (61.9\%) and the freshwater shrimp "uwang" (47.3\%), "moli" fish (15\%) and the eel "kasili" $(11 \%)$ (Table 8). 
Table 8. Economically important biological resources in Pagbanganan River

\begin{tabular}{lccc}
\hline \hline Biological Resource & Local Name & Frealuency & \% of Responses \\
\hline Fish: & Tilapia & 27 & \\
Oreochromis sp. & Moli & 15 & 49.1 \\
Poecilia sp. & Kasili & 11 & 27.3 \\
Anguilla sp. & Damagan & 7 & 20.0 \\
Kuhlia sp. & Karpa & 6 & 12.7 \\
Cyprimus sp. & Halwan & 4 & 10.9 \\
Chamna sp. & Kikilo & 2 & 7.3 \\
Scatophagus sp. & Agok-ok & 2 & 3.6 \\
Clarias sp. & & 74 & 3.6 \\
\hline Total responses & & & \\
\hline Invertebrates: & Bukgay, Susu & 34 & 61.9 \\
Freshwater snail & Uwang & 26 & 47.3 \\
Freshwater shrimp & Alimango & 2 & 3.6 \\
Freshwater crab & & 62 & \\
\hline Total responses & & &
\end{tabular}

\section{River and/or Water Quality Assessment}

A quarter of the respondents $(24.7 \%)$ experienced waterrelated diseases as a result of bathing in the river while $75.3 \%$ did not (Table 9). For those who experienced infection or water-related diseases, they experienced skin diseases such as itching and skin allergies $(94.7 \%)$, loose bowel movement or LBM (5.3\%), cough and flu (5.3\%). Usually children were the most affected (52.7\%).

Those infected said that they contacted the disease in the year $2010(26.3 \%)$ while $21.1 \%$ claimed they got it every time they take a bath or cross the river. Almost half of those who were infected treated their infections with over-the-counter drugs (47.4\%), more than thirty percent $(31.6 \%)$ used herbal medicines and $15.8 \%$ seek the help from quack doctors. In terms of accidents or disasters that happened in the river, $61 \%$ confirmed their occurrence, which include flooding $(89.1 \%)$ and people drowning $(10.9 \%)$. These accidents usually happened during typhoons and heavy rains. 
Table 9. Incidence of river-related diseases and accidents or disasters

\begin{tabular}{|c|c|c|c|}
\hline & & Freauency & Percent \\
\hline \multicolumn{4}{|l|}{ Disease incidence: } \\
\hline $\begin{array}{l}\text { Got infected } \\
\text { Did not occur }\end{array}$ & & 19 & 24.7 \\
\hline \multirow[t]{2}{*}{ Did not occur } & & 58 & 75.3 \\
\hline & Total & 77 & 100.0 \\
\hline \multicolumn{4}{|l|}{ Type of disease: } \\
\hline Itchiness/Skin Allergy) & & 18 & 94.7 \\
\hline Loose Bowel Movement (LBM) & & 1 & 5.3 \\
\hline \multirow[t]{2}{*}{ Cough and flu } & & 1 & 5.3 \\
\hline & Total & 20 & \\
\hline \multicolumn{4}{|l|}{ Persons infected with the disease: } \\
\hline Children & & 10 & 52.7 \\
\hline Father & & 4 & 21.1 \\
\hline Mother & & 3 & 15.8 \\
\hline Whole family & & 2 & 10.5 \\
\hline \multirow[t]{2}{*}{ Other household members } & & 3 & 15.9 \\
\hline & Total & 22 & \\
\hline \multicolumn{4}{|l|}{ Time of disease oceurrence: } \\
\hline 2010 & & 5 & 26.3 \\
\hline Every after bathing or crossing the river & & 4 & 21.1 \\
\hline 2011 & & 4 & 21.1 \\
\hline Past five or more years & & 3 & 15.8 \\
\hline Every vear & & 1 & 5.3 \\
\hline Past two to four years & & 1 & 5.3 \\
\hline \multirow{2}{*}{ Sometimes } & & 1 & 5.3 \\
\hline & Total & 19 & 100.0 \\
\hline \multicolumn{4}{|l|}{ Do with the disease: } \\
\hline Buy over the counter drugs & & 9 & 47.4 \\
\hline Used herbal/ native medicine & & 6 & 31.6 \\
\hline Consult quack doctor & & 3 & 15.8 \\
\hline \multirow[t]{2}{*}{ Consult doctor } & & 1 & 5.3 \\
\hline & Total & 19 & 100.0 \\
\hline \multicolumn{4}{|l|}{ Occurrence of accidents/disasters: } \\
\hline Occurred & & 47 & 61.0 \\
\hline \multirow{2}{*}{ Did not occur } & & 30 & 39.0 \\
\hline & Total & 77 & \\
\hline \multicolumn{4}{|l|}{ Type of disaster/accident: } \\
\hline Flooding & & 41 & 89.1 \\
\hline \multirow[t]{2}{*}{ Drowning } & & 5 & 10.9 \\
\hline & Total & 46 & \\
\hline
\end{tabular}

Figure 6 shows that flooding is the main problem in the river $(90.3 \%)$, followed by water pollution due to improper garbage disposal $(40.3 \%)$, erosion of the riverbanks $(19.4 \%)$, poor water quality $(14.5 \%)$, quarrying $(14.5 \%)$ and water-borne diseases $(12.9 \%)$. 


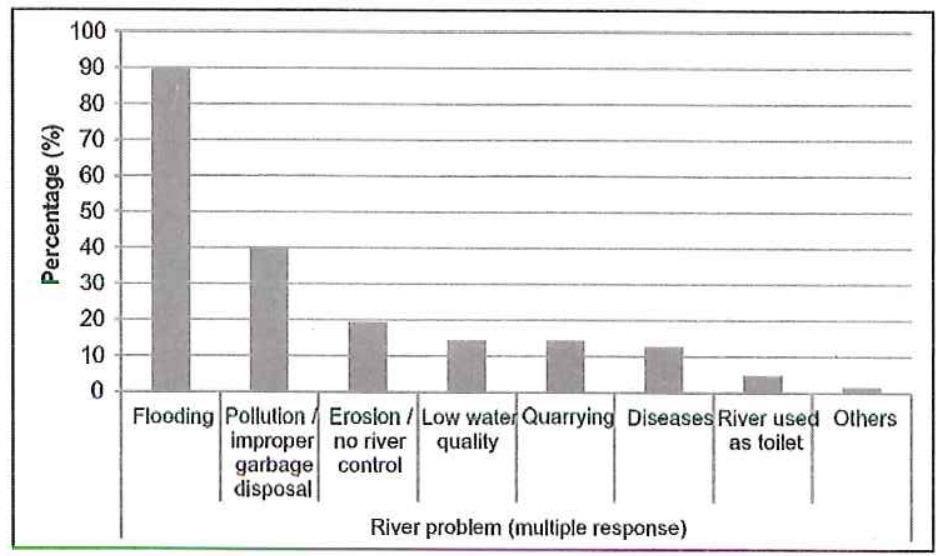

Figure 6 . River problems mentioned by the respondents

Table 10 presents the actions taken by the community if flooding and other disasters occurred in the river. Whenever there is flooding, $54.9 \%$ of the respondents just stay at home (54.9\%), some evacuate $(17.6 \%)$ while others just monitor the situation and get ready to evacuate in case the situation worsens $(13.7 \%)$. For erosion problem, majority just do nothing $(42.7 \%)$, others constructed dikes or report the problem to the barangay officials $(28.6 \%)$. For low water quality, majority does not care and continue using the river (42.9\%) while the rest avoided using the river for bathing $(28.6 \%)$ or laundry $(14.3 \%)$. 
Table 10. Actions taken related to flooding, erosion and low water quality

\begin{tabular}{lcc}
\hline Do with flooding & Frequency & Percent \\
\hline None at all/stay at home & 28 & 54.9 \\
Evacuate & 9 & 17.6 \\
Get ready/monitor the situation & 7 & 13.7 \\
Wait until flood water is gone & 3 & 5.9 \\
Pick up coconut/woods carried by flood & 2 & 3.9 \\
Report to barangay official about illegal logging & 2 & 3.9 \\
\hline Total & 51 & 100.0 \\
\hline Do with erosion & & \\
None & 3 & 42.9 \\
Make a dike & 2 & 28.6 \\
Report to barangay official & 2 & 28.6 \\
\hline Total & 7 & 100.0 \\
\hline Do with low water quality & & \\
\hline None at all & 3 & 42.9 \\
Won't take a bath in the river & 2 & 28.6 \\
Choose river area with cleaner water & 1 & 14.3 \\
Won't do laundry in the river & 1 & 14.3 \\
\hline Total & 7 & 100.0 \\
\hline
\end{tabular}

As to the respondents' perception of water quality of the river, results show that in the past three years, almost $50 \%$ of the respondents claimed that the water in the river was clean while only $39 \%$ said it was polluted (Fig. 7). For the current state of the river, the respondents were divided in terms of their perception because $42.1 \%$ said that the river is clean and the same percentage claimed that it is now polluted. In the next three years, $35.1 \%$ said that they cannot predict the water quality. About $36.4 \%$ thought that it would become polluted while $28.6 \%$ were optimistic that it will remain clean. 


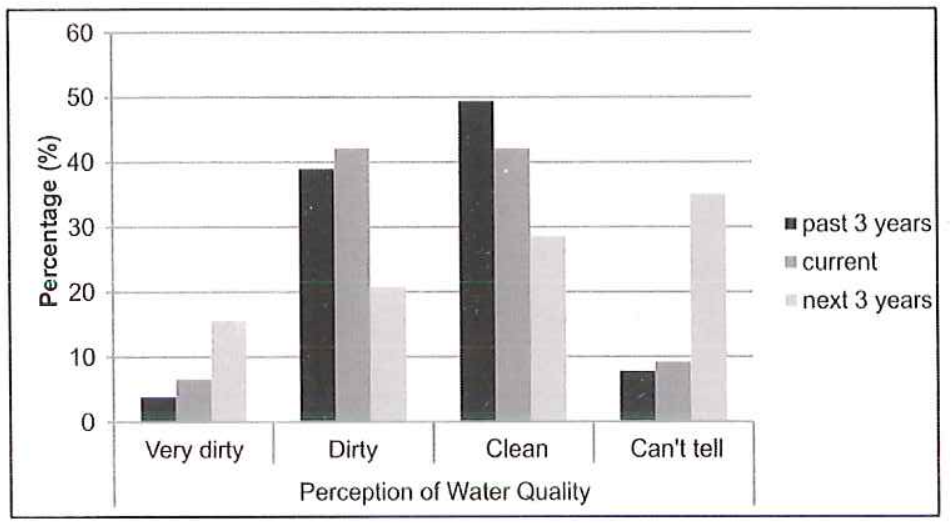

Figure 7. Assessment of water quality by respondents

From the results, it can be shown that the respondents perceived a decreasing trend in water quality across years. In the past 3 years, $49.4 \%$ said it was clean, $42.1 \%$ said it is presently clean but if current practices in the river continue, only $28.6 \%$ said that the water would still be clean in the next three years. The perception of the respondents as to the water quality of the river is declining in terms of its cleanliness. This change in the perception could serve as a warning that if nothing will be done, there is a tendency of eroding the river's water quality in the future. Something should be done on this regard because poor people are residing near the river and depending on it for food and other home-related services.

Figures 8 and 9 show how much the people value the river. Majority of the respondents (77\%) consider the river in its entirety as important. As to the quality of the water in the river, $79 \%$ said it is important. Interestingly, one of the possible reasons why the residents value the river was because most of them $(61.9 \%)$ still believed that supernatural beings reside in the river as evidenced by the many superstitious beliefs they have. 


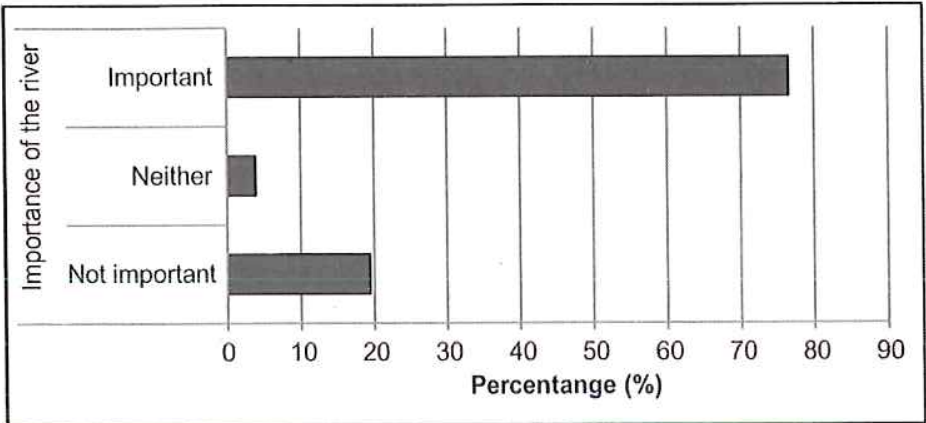

Figure 8. Importance of Pagbanganan River as perceived by the respondents

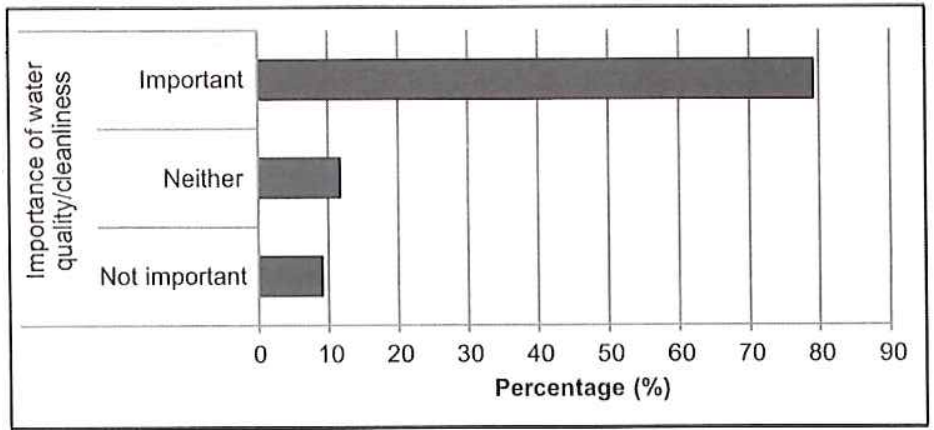

Figure 9. Importance of water quality or cleanliness of Pagbanganan River as viewed by respondents

Based on the above information, it can be deduced that the people along the river do recognize the importance and value of the river and that there are pressing problems, which could have negative effects on its water quality, biodiversity and on the other services that it provides to the community. 


\section{Comparison of Biological Assessment of Water Quality and the Peoples' Perceptions}

Based on the previous study employing biological assessment of water quality using planktonic algae as bioindicator, there is only "less" to "probable" organic pollution in Pagbanganan River (Labonite, 2012). This means that in general, the river cannot yet be considered as strictly "unsafe" for use. However, based on local residents' perceptions, the river at present is neither clean nor polluted with $42.1 \%$ saying it is clean and another $42.1 \%$ saying it is polluted. What is important, however, is that they generally agreed and believed that the water quality is indeed slowly deteriorating.

Though the results focused only on the assessment of local communities, results show that local communities were conscious and aware of the river's present status and that they have the ability to foresee future scenarios in the event that they do not take actions to protect and sustainably utilize the river and the various biological resources and services they derive from it.

\section{CONCLUSIONS}

The study affirms that Pagbanganan River has an integral part to the people living near the area. The residents believed that water quality in the river has been slowly deteriorating. However, they have opposing views regarding the present water quality status of the river, which means that they have no definite or clear idea on how to determine the degree of pollution of the water body. Results suggest that raising awareness on water quality issues, such as sanitation, solid waste disposal and others to concerned target groups is necessary to increase people's understanding and encourage behavioral changes towards effective water resource management. In addition, proper implementation of local policies to protect the river from further degradation should be done. To corroborate the results of the study, further study on the assessment of water quality using biological indicators is necessary. 


\section{LITERATURE CITED}

ALVARADO, A.C. 2005. Geomorphological Characterization and Discharge Determination of the Pagbanganan River Watershed. Undergraduate Thesis, Leyte State University, Visca, Baybay, Leyte. pp. 1-54

BENNETT, E.M., G.D. PETERSON AND L.J. GORDON. 2009. Understanding relationships among multiple ecosystem services. Ecology Letters 12:1-11.

ELLEN, S. 2011. Slovin's Formula Sampling Technique. Retrieved August 2011 from http://www.ehow.com/way _5475547_ slovins-formula-sampling-techniques.html.

LABONITE, E.K.A. 2012. Planktonic algae as bioindicators of water quality in Pagbanganan River, Baybay City, Leyte. Unpublished MS Thesis, Visayas State University, Visca, Baybay City, Leyte, 144p.

LABONITE, E.K.A. and B.S. BELONIAS. 2013. Community structure of planktonic algae in Pagbanganan River, Baybay City, Leyte. Science and Humanities Journal, 10:54-82

NATIONAL STATISTICAL COORDINATION BOARD (NSCB). 2012. Poverty Statistics, Annual Per Capita Poverty Thresholds by Province, 2006-2007. Retrieved FEbriary 2012 from www.nscb.gov.ph.

REDMAN C., J.M. GROVE AND L. KUBY. 2004. Integrating social science into the Long Term Ecological Research (LTER) network: social dimensions of ecological change and eological dimen- sions of social change. Ecosystems (7):161-71.

ViÉ, J.C., C. HILTON-TAYLOR and S.N. STUART. 2009. Wildlife in a Changing World - An Analysis of the 2008 IUCN Red List of Threatened Species. Gland, Switzerland: IUCN.180 pp. 